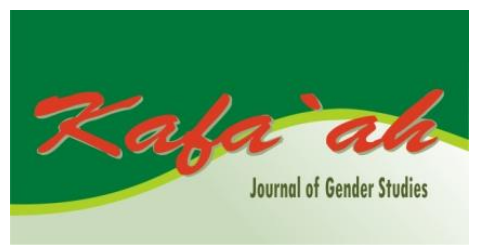

KAFA'AH JOURNAL, 8 (2), 2018

(Print ISSN 2356-0894 Online ISSN 2356-0630)

Available online at : http://kafaah.org/index.php/kafaah/index

\title{
Membangun Keberdayaan Perempuan Single Parent di Batu Hampa Kabupaten Pesisir Selatan
}

\author{
Lukmanul Hakim \\ Email: luqman_az01@yahoo.com \\ UIN Imam Bonjol Padang \\ Ahmad Syarifin \\ IAIN Bengkulu \\ Ihsan Sanusi \\ IAIN Batusangkar \\ Aziza Meria \\ UIN Imam Bonjol Padang
}

\begin{abstract}
This article is to describe and analyze the aspirations and needs of single parent women in the context of empowerment through religious education and entrepreneurship and to analyze patterns of empowering entrepreneurial religious education that are relevant for single parents. This research was conducted by using Participatory Action Research (PAR). The techniques include: transects, interviews and Focus Group Discussion (FGD). Factors that cause the low management and utilization in Batu Hampa Village are: economic factors - limited capital, and intermediary factors that facilitate and allow the rooted inability of single parent women and Low Human Resources of single parent women.
\end{abstract}

Keywords: own feet, empowerment and single parent

\begin{abstract}
Abstrak
Tulisan ini adalah untuk mendeskripsikan dan menganalisis aspirasi dan kebutuhan perempuan single parent dalam rangka pemberdayaan melalui pendidikan keagamaan dan kewirausahaan menganalisis pola pemberdayaan pendidikan keagamaan kewirausahaan yang relevan bagi single parent. Penelitian ini dilakukan dengan menggunakan metode Participatory Action Research (PAR). Teknik yang digunakan meliputi: transek, wawancara, Focus Group Discussion (FGD). Faktor yang dapat diasumsikan menjadi penyebab mendasar masih rendahnya pengelolaan dan pemanfaatan pekarangan di Kenagarian Batu Hampa, seperti: faktor ekonomi-keterbatasan modal, dan faktor perantara yang memfasilitasi dan memungkinkan terus mengakarnya ketidakmampuan perempuan single parent serta rendahnya Sumber Daya Manusia perempuan single parent, sehingga mereka tidak mampu merencanakan dan mengelola pekarangan yang mereka miliki.
\end{abstract}

Kata Kunci : kaki sendiri, keberdayaan dan single parent

\section{PENDAHULUAN}

Pertumbuhan keluarga dengan orang tua tunggal atau single parent saat ini merupakan fenomena yang terus berlangsung. Hal ini menjadi pertanyaan banyak kalangan mulai dari pemerintah, praktisi pendidikan hingga sosiolog. Fenomena dimaksud tidak hanya terjadi di wilayah perkotaan melainkan juga pada wilayah pedesaan. Mulai dari 
kelompok intelektual sampai kelompok masyarakat awam, sebagaimana halnya di Kenagarian Batu Hampa Kecamatan Koto XI Tarusan (Profil, n.d.). Kenagarian Batu Hampa terdiri dari 4 Jorong (kampung), yakni kampung Tarandam, Batu Patah, Pondok dan Sawah Laweh. Berdasarkan data awal yang ditemukan dari empat kampung tersebut terdapat 50 orang perempuan janda yang memiliki anak usia sekolah dan tergolong dalam usia muda. Dari jumlah tersebut 33 berasal dari Kampung Tarandam, 4 orang dari Batu Patah, dari Pondok 9 orang dan dari Sawah Laweh 4 orang (Malin Mudo, n.d.).

Kajian ini penting untuk dijadikan fokus pehatian, mengingat pemahaman masyarakat terhadap nilai-nilai tradisional yang sangat kuat bahwa perempuan harus menikah. Oleh karena itu status single parent (janda) cenderung untuk dihindari, karena menurut masyarakat hal ini adalah suatu 'aib, baik bagi dirinya maupun bagi keluarganya bahkan bagi lingkungan. Karenanya single parent cenderung menutup diri. Sebagaimana disampaikan oleh Dewi (informan) "sia nan nio jadi jando ko, tapi ba a lai, laki awak pai baitu se nan awak indak lo dapek babuek apo-apo do. Kini awak jo anak se, kok masalah malu yo lah malu awak jo dunsanak co itu lo jo urang kampuang ko (Dewi, n.d.). (Siapa yang ingin menjadi janda, tapi mau bagaimana lagi, suami saya pergi begitu saja, dan saya tidak dapat berbuat apaapa. Sekarang saya dengan anak, kalau masalah malu, saya malu dengan keluarga juga dengan orang sekampung).

Disadari atau tidak, hal ini juga akan berpengaruh terhadap kehidupan sosial, mempengaruhi akses mereka terhadap sumber-sumber pembangunan. Hal penting lainnya, saat ini dapat dikemukakan bahwa perempuan single parent dalam mengakses programprogram pembangunan yang dilaksanakan pemerintah cenderung mengembangkan pola perilaku pasif, karena perasaan malu sehubungan dengan status yang dimilikinya. Programprogram pemerintah untuk perempuan cukup banyak, misalnya melalui program PNPM ada simpan pinjam khusus untuk perempuan (SPP). Kemudian pelatihanpelatihan keterampilan seperti makanan olahan. Namun perhatian pemerintah khusus terhadap perempuan single parent terbilang rendah, belum ada programprogram khusus yang menaungi perempuan single parent. Karena stereotype yang berkembang dan rendahnya pemahaman mereka terhadap program-program yang telah ditawarkan pemerintah. Ada kecenderungan bahwa keterlibatan mereka terhadap programprogram pemerintah lebih banyak disebabkan adanya keberpihakan petugas pelaksana program, bukan karena inisiatif mereka sendiri. Sebagai contoh sudah banyak single parent di Kenagarian Batu Hampa ini yang terlibat sebagai Kader di Posyandu, Kegiatan Lansia dan PKK serta PNPM mandiri.

Pada bagian lain minimnya pemahaman keagamaan dan terbatasnya akses dapat memberikan dampak negatif pada keluarga single parent. Seperti kemiskinan yang akan memberikan efek gangguan emosional kepada orang tua, yang berpengaruh terhadap cara mereka dalam mengasuh anak-anak, maka orang tua cenderung mengasuh anak dengan cara yang tidak tepat dan tidak proporsional. Misalnya bagi perempuan single parent merupakan kewajiban bagi mereka untuk mengerjakan seluruh pekerjaan rumah tangga, bahkan untuk mencari penghasilan. Seperti Dewi anaknya baru berusia 3 minggu, untuk menghidupi keluarganya ia berjualan makanan ringan tradisional-kerupuk sate-di depan rumahnya. Bahkan anak yang seharusnya bermain atau bersekolah terpaksa harus ikut orang tuanya bekerja dan bergaul dengan orang yang lebih tua. Karena jika anak sering di luar maka komunikasi dengan orang tua menjadi 
tidak efektif, hasilnya anak-anak berpotensi menjadi korban, yang bisa berujung pada terciptanya keluarga broken home.

Kondisi seperti ini umumnya dialami oleh perempuan single parent. Karena itu pemberdayaan perempuan single parent menjadi penting, sehingga keberlangsungan hidup keluarga tersebut dapat setara dengan keluarga yang utuh dan dapat mengembangkan diri dan keluarga, baik dalam bidang pendidikan, ekonomi, sosial maupun akses pembangunan lainnya. Secara khusus tulisan ini difokuskan pada pembinaan dan penguatan kepada perempuan single parent baik secara keagamaan maupun ekonomi.

Ada beberapa alasan mendasar mengapa perempuan single parent yang dipilih menjadi objek dampingan, pertama; dari hasil survei awal yang dilakukan diperoleh data bahwa permasalahan single parent dapat dikatakan masalah serius yang semakin meluas, untuk itu perlu pengkajian serius dan mendalam. Kedua; berdasarkan studi yang dilakukan belum ditemukan tim peneliti kelompok atau program-program sejenis yang memberikan perhatian khusus kepada single parent. Sementara kelompok single parent secara kuantitas termasuk komunitas yang banyak di tengah-tengah masyarakat. Ketiga, permasalahan single parent dinilai sebagai persoalan mendesak dan perlu dilaksanakan segera agar kondisi masyarakat tidak semakin buruk. Keempat; Single parent merupakan kondisi yang perlu mendapatkan perhatian, salah satu masalah utama yang pelik yang dihadapi banyak single parent adalah masalah finansial. Apalagi banyak ayah yang setelah bercerai mengabaikan kewajibannya untuk memberikan nafkah hidup kepada anak-anaknya. Kelima; Umumnya perempuan single parent memiliki pemahaman keagamaan yang rendah namun di sisi lain mereka juga kurang berminat dalam mengikuti kegiatan-kegiatan keagamaan. Jika ini dibiarkan maka akan menjadi berlarut dan pemahaman masyarakat terhadap agama tidak akan berubah.

Permasalahan dalam penelitian ini adalah bagaimana aspirasi dan kebutuhan perempuan single parent dalam rangka pemberdayaan melalui pendidikan keagamaan dan kewirausahaan yang relevan.

\section{METODE PENELITIAN}

Penelitian ini dilakukan dengan menggunakan metode Participatory Action Research (PAR) (Kemmis \& McTaggart, 2005). Action research adalah proses spiral yang meliputi perencanaan tindakan yang melibatkan investigasi yang cermat, kemudian pelaksanaan tindakan dilanjutkan penemuan fakta-fakta tentang hasil dari tindakan, serta penemuan makna baru dari pengalaman sosial. Lebih lanjut dikemukakan oleh Corey bahwa action research adalah proses dimana kelompok sosial berusaha melakukan studi masalah mereka secara ilmiah dalam rangka mengarahkan, memperbaiki, dan mengevaluasi keputusan dan tindakan mereka (Bitha, 2011). Hopkins mengemukakan action research merupakan upaya untuk mengkonstribusikan baik pada masalah praktis pemecahan masalah maupun pada tujuan ilmu sosial itu sendiri dengan mengkolaborasikan di dalamnya yang dapat diterima oleh kerangka kerja etik, sedangkan Peter Park menilai bahwa action research, merupakan cara penguatan masyarakat melalui penyadaran diri untuk melakukan tindakan yang efektif menuju perbaikan kondisi kehidupan mereka (Ahmad, 2003).

Alur aktifitas program action research adalah cyclical, berupa siklus kegiatan yang berulang dan berkesinambungan. Dalam konteks 
program action research ini, siklus kegiatannya terdiri dari kegiatan (mapping), penyusunan rencana tindak (action planning), pelaksanaan rencana tindak (implementation), monitoring dan evaluasi. Hasil monitoring dan evaluasi tersebut untuk selanjutnya dipetakan kembali dan kemudian dilakukan penyusunan ulang rencana tindak (replan), implementasi, monitoring dan evaluasi, dan terus kembali berulang.

Setiap selesai satu tahapan kegiatan, sesuai dengan prinsip dasar riset aksi, dilakukan kegiatan refleksi untuk mengetahui tingkat keberhasilan masing-masing tahapan. Oleh karena itu, program tindak lanjut dari riset ini pada dasarnya merupakan aktifitas pengulangan dari kegiatan refleksipemetaan ulang penyusunan rencana tindak-pelaksanaan rencana tindak, dan monitoring dan evaluasi. Namun demikian, ada beberapa penekanan yang akan dilakukan, yakni: peningkatan kemandirian dan kinerja perempuan single parent, peningkatan pemahaman keagamaan keluarga perempuan single parent, penguatan misi transformasi social masyarakat khususnya perempuan single parent, penguatan networking dan aliansi strategis antar perempuan.

Program

pemberdayaan perempuan single parent ini pada hakikatnya adalah sebuah "riset aksi". Oleh karena itu, pelaksanaannya secara umum mengelaborasi konsep Participatory Action Research (PAR) dengan berbagai modifikasi. Sesuai dengan prinsip emancipatory research dan collaborative resources yang menjadi bagian penting dari ciri sebuah riset aksi, maka dalam pelaksanaan program pemberdayaan perempuan single parent ini, mereka berperan sebagai main actor. Sedangkan peneliti sekedar "pendamping" yang semaksimal mungkin berusaha untuk meningkatkan kemampuan dan partisipasi stakeholders perempuan single parent, memetakan dan merumuskan masalah, membuat rencana tindak, melaksanakan program kegiatan, memantau dan mengevaluasi setiap proses implementasi program.

Pada setiap tahapan dan proses tersebut, peneliti juga berusaha membangun suasana dan menciptakan iklim yang kondusif, memberi berbagai masukan (input), meningkatkan capacity, membuka akses ke berbagai networking, peluang, dan kesempatan (opportunities) yang ada di luar komunitas perempuan single parent.

Dalam pengumpulan data mengacu pada metodologi penelitian PAR secara umum yakni dengan teknik transek (Penelusuran Desa) yang digunakan bersama masyarakat dalam melakukan pengamatan langsung kondisi lingkungan. Langkah awal dilakukan dengan berjalan menelusuri wilayah nagari dan jorong mengikuti yang telah disepakati sebelumnya. Jenis-jenis transek yang dilakukan meliputi transek sumber daya nagari dan jorong umum, transek sumber daya alam, transek topiktopik tertentu. Melalui transek ini diharapkan peneliti dapat mengamati langsung ke lokasi kenagarian dan menelusuri kenagarian, selanjutnya untuk mengetahui potensi dan kegiatan yang dilakukan masyarakat juga memperoleh gambaran keadaan sumber daya alam masyarakat beserta masalah-masalah, perubahan-perubahan keadaan dan potensi-potensi yang ada. Dan tidak kalah pentingnya adalah untuk mengenali secara lebih mendalam problem-problem sosial yang ada di Kenagarian Batu Hampa.

Dalam pelaksanaannya bersama dengan masyarakat menyepakati lokasilokasi penting yang akan dikunjungi serta topik-topik kajian yang akan dilakukan, siapa saja yang terlibat, baik untuk pengamatan maupun untuk pencatatan dan pendokumentasian. Langkah selanjutnya bersama warga dibuat kesepakatan simbol-simbol yang akan 
dipergunakan. Simbol-simbol tersebut menunjukkan arti atau lambang tentang sesuatu dari yang dicatat.

Wawancara mendalam kepada pihak terkait yaitu pihak pemerintah nagari, masyarakat dan khususnya perempuan single parent. Dalam wawancara mengkaji mengenai potensi desa, kehidupan ekonomi dan sosial serta keagamaan keluarga perempuan single parent. Focus Group Discussion (FGD), yaitu diskusi kelompok terfokus yang melibatkan perempuan single parent, wali nagari, pada FGD ditujukan untuk memperoleh informasi mengenai harapan masa depan, solusi bersama untuk mengatasi masalah keluarga perempuan single parent. Dalam merumuskan masalah keluarga single parent melalui form belanja rumah tangga (pangan, energy, accessories, kesehatan, pendidikan dan sosial). Form ini disebarkan kepada keluarga single parent dan diberikan contoh pengisian dengan jelas. Melalui form ini diharapkan dapat ditemukan sendiri oleh masyarakat halhal yang sesungguhnya yang menjadi masalah dalam rumah tangga.

Data sekunder diperoleh dari informasi yang dipublikasikan oleh lembaga berkepentingan seperti Dinas Perindustrian, BAPPEDA Pesisir Selatan, Kantor Wali Nagari, media cetak, media elektronik, maupun literatur. Pengumpulan data dilakukan dengan cara partisipatif mulai dari perumusan masalah, setelah itu peneliti dan pihak yang diteliti mengerjakan secara bersama-sama solusi yang harus dijalankan. Data kuantitatif dilakukan pada tahap validasi data untuk membuktikan kebenaran data. Data yang ditemukan selanjutnya dianalisis dengan teknik: Pohon Analisis Masalah dan Pohon Analisis Tujuan dan selanjutnya menggunakan matrik analisis partisipasi dan rencana aksi bersama masyarakat.

Proses analisis dan pengolahan data ini dilakukan dengan prinsip partisipatif, fathnership, perluasan jaringan. Dengan diskusi diharapkan dapat disadari permasalahan yang dihadapi oleh dampingan hingga akhirnya nanti dapat dirumuskan aksi yang akan dilaksanakan.

\section{HASIL DAN PEMBAHASAN}

\section{A. Menuju Kemandirian}

Kegiatan pemberdayaan perempuan single parent melalui pemanfaatan pekarangan yang dilaksanakan dengan pendekatan Partisipatory Action Research (PAR) telah ditetapkan sebagai target ketercapaian program. Untuk dapat diketahui keberhasilan program pemberdayaan perempuan single parent tersebut dengan pendekatan PAR pada fase pertama ini dapat dianalisis berdasarkan matrik indikator ketercapaian program sebagai berikut:

Tabel 1:

Matrik Indikator Kinerja

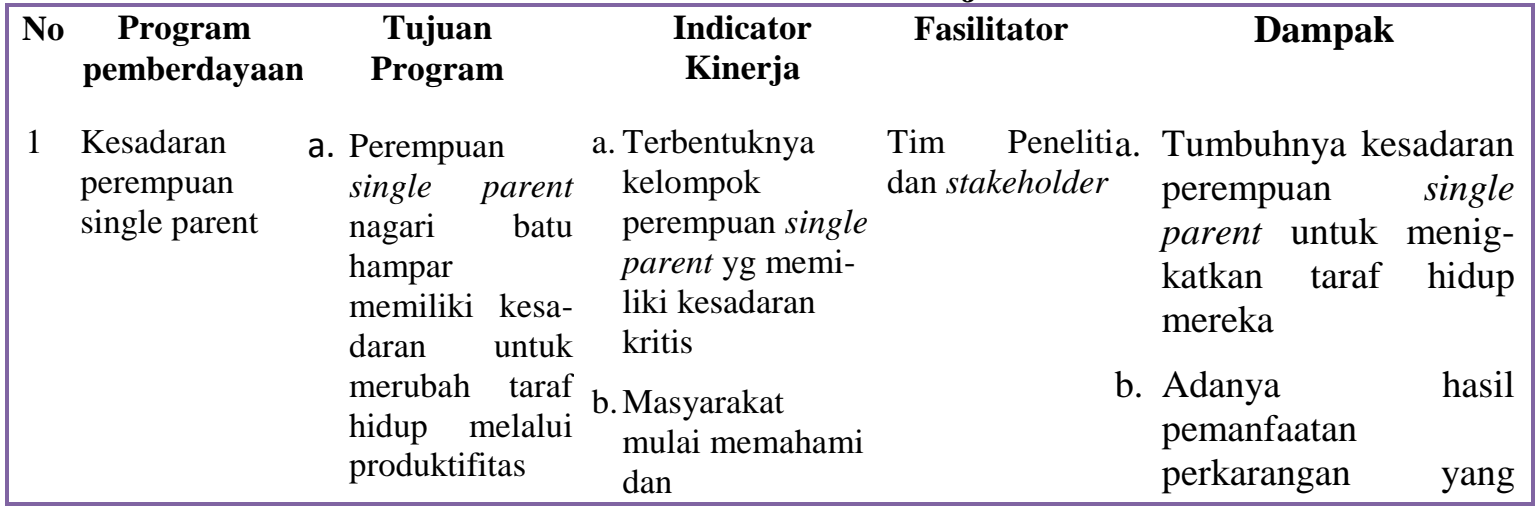




\begin{tabular}{|c|c|c|c|c|c|}
\hline 2 & $\begin{array}{l}\text { Keterlibatan } \\
\text { tokoh lokal }\end{array}$ & $\begin{array}{l}\text { pekarangan } \\
\text { b. Masyarakat } \\
\text { dengan } \\
\text { kesadaran } \\
\text { kolektif } \\
\text { menjadikan } \\
\text { pemanfaatan } \\
\text { pekarangan } \\
\text { sbg. acuan } \\
\text { dlm pening- } \\
\text { katan taraf } \\
\text { hidup a } \\
\text { a. Tokoh lokal } \\
\text { menyadari dan } \\
\text { mendukung } \\
\text { upaya } \\
\text { pemberdayaan } \\
\text { pemberdayaan } \\
\text { perempuan } \\
\text { b. Tokoh lokal } \\
\text { berperan aktif } \\
\text { untuk mempe- } \\
\text { ngaruhi } \\
\text { pemerintahan b. } \\
\text { dan pihak } \\
\text { terkait dalam } \\
\text { membuat } \\
\text { kebijakan yang } \\
\text { mendukung } \\
\text { bagi perempuan }\end{array}$ & $\begin{array}{l}\text { Tokoh lokal } \\
\text { terlibat secara } \\
\text { langsung } \\
\text { dengan } \\
\text { memberikan } \\
\text { pemikiran } \\
\text { dalam upaya } \\
\text { peningkatan } \\
\text { ekonomi } \\
\text { perempuan } \\
\text { single parent } \\
\text { Tokoh lokal } \\
\text { terlibat } \\
\text { langsung dlm } \\
\text { merumuskan } \\
\text { langkah- } \\
\text { langkah } \\
\text { pemberdayaan } \\
\text { ekonomi } \\
\text { perempuan } \\
\text { single parent } \\
\text { dan pendidikan } \\
\text { keagamaan }\end{array}$ & $\begin{array}{l}\text { a. Tim Peneliti,,a. } \\
\text { stakeholder, } \\
\text { wali nagari, } \\
\text { wali kampung } \\
\text { b. Tim Peneliti b. } \\
\text { dan tokoh } \\
\text { lokal }\end{array}$ & $\begin{array}{lr}\begin{array}{l}\text { Melakukan } \\
\text { dalam pendekatan } \\
\text { kesadaran } \\
\text { perempuan single parent }\end{array} \\
\text { Melakukan pendekatan } \\
\text { persuasive } \\
\text { membnagun kesadaran } \\
\text { kritis perempuan single } \\
\text { parent }\end{array}$ \\
\hline
\end{tabular}

Mengamati matrik indikator ketercapaian program yang dapat dilihat kinerja di atas dapat diketahui bahwa : pada matrik berikut:

Tabel 2:

Matrik Indikator Ketercapaian Program

Tujuan program

a. Membangun kerjasama dengan pemerintahan nagari dan tokoh lokal

b. Pemberdayaan perempuan single parent bersama masyarakat

\section{Indikator}

Indikator Ketercapaian

a. Terselengaranya pertemuan formal maupun nonformal membahas bentuk program pemberdayaan

b. Disepakatinya program dampingan yang didukung oleh semua pihak yang terlibat dalam masyarakat

c. Peninjauan kembali program yang telah dilakasanakan dengan mengidentifikasi temuan, kelemahan dan kelebihan a. Adanya kesepakatan antara pendamping dan yang akan didampingi

b. Teridentifikasinya kelemahan dan kelebihan program kebijakan pemerintah sebelum program ini dilakasanakan

c. Tersusunnya desain pemberdayaan perempuan single parent oleh Tim Peneliti. Yakni:

1) Kerangka pemberdayaan perempuan single parent

2) Fasilitator pendamping 3) Sasaran pemberdayaan
Perguruan

\section{Lembaga \\ Pendamping}

Perguruan Tinggi Tinggi

Perguruan

Tinggi \& Wali 


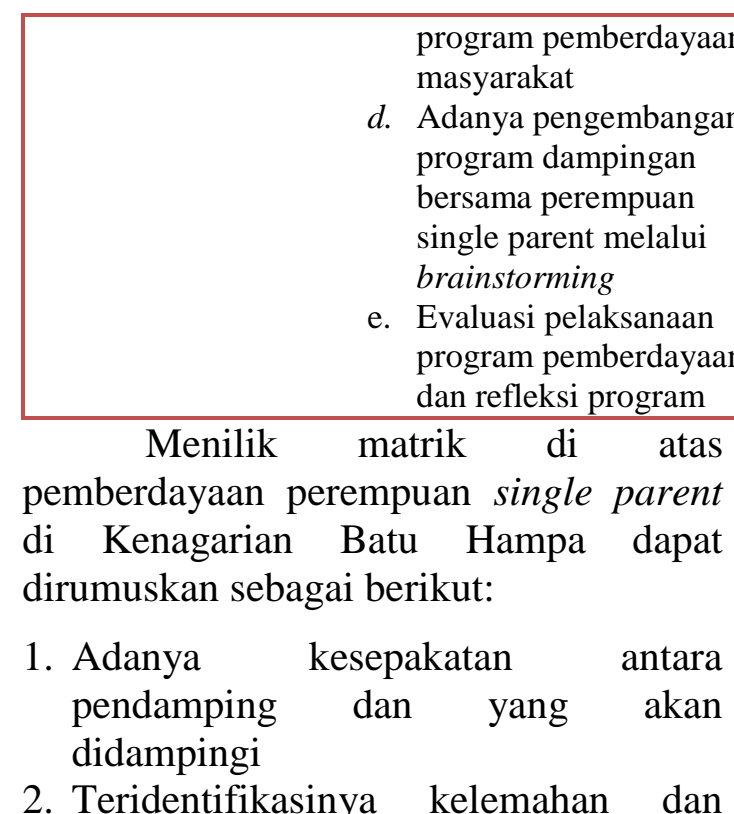
kelebihan program kebijakan pemerintah sebelum program

3. Tersusunnya desain pemberdayaan perempuan single parent dengan mengacu pada kerangka pemberdayaan perempuan single parent, fasilitator, sasaran, proses pelaksanaan dan evaluasi pelaksanaan program

4. Tersusunya hasil program pemberdayaan bagi perempuan single parent

\section{B. Cerdas Bersama Masyarakat (Single Parent)}

Berdasarkan program yang telah dilaksanakan kemudian capaian-capaian yang terlihat dari hasil refleksi maka dapat dilakukan analisis beberapa dampak program pemberdayaan

\section{Dampak bagi Lembaga Pendamping}

1. Hubungan antara Lembaga Swadaya Masyarakat (LSM), masyarakat, pemerintah dalam mengembangkan fungsi dan tanggung jawab sosial dan kemanusiaan semakin kuat. Hal ini menjadi langkah awal bagi Perguruan Tinggi selaku lembaga pendidikan untuk mengembangkan pendidikan masyarakat tahap selanjutnya

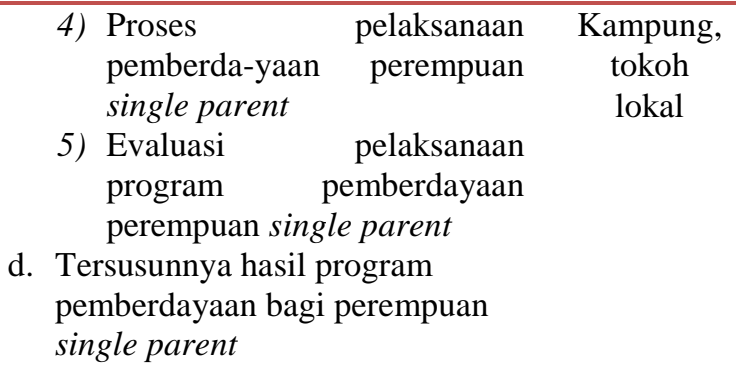

2. Mengembangkan kesadaran kritis bagi masyarakat khususnya perempuan single parent sebagai konsekuensi perubahan sosial (sociol change) dalam menghadapi persaingan regional dan global serta memperkuat kemampuan perempuan single parent dalarn menganalisis setiap kebijakan atau peraturan yang tidak sesuai dengan kebutuhan mereka atau bahkan dapat merugikan kehidupan mereka dalam jangka panjang

3. Mempersiapkan diri sebagai lembaga swadaya yang peka, teliti, dan menjadi sumber inspirasi, mediasi dan aksi perempuan dalam mengembangkan pendidikan secara partisipatif

4. Memberikan solusi untuk mengatasi masalah yang dihadapi oleh perempuan sebagai sumbangsih pemikiran dan tanggung jawab perguruan tinggi dalam rangka ikut serta memperlancar proses pembangunan di daerah

\section{Dampak bagi Single Parent}

1. Meningkatknya kesadaran kritis perempuan single parent baik dalam sistem budaya, sosial, politik, ekonomi, dan lain-lainnya (Fakih, n.d.; Mansour, 2000; Rahardjo, Fakih, \& Topatimasang, 2001; Toto Suharto, 2012).

2. Telah mampu menganalisis secara kritis dan mengkaji permasalahan pembangunan dari sudut pandang perempuan secara langsung atas kebijakan atau peraturan dalam pembangunan yang dilaksanakan oleh pemerintah daerah (Faqih, 2010; Mansour, 2001). 
3. Timbulnya rasa memiliki (sense of belonging) perempuan dalam mengelola dan memanfaatkan sumber daya yang ada (George, 2007)

4. Berperan serta secara langsung dalam memberdayakan diri mereka sendiri untuk mengatasi masalah yang dihadapi dengan mengembangkan potensi yang dimiliki

5. Mampu menyampaikan permasalahan yang dihadapi dan dengan sikap kritis berupaya mencari solusi dari permasalahan tersebut

\section{Dampak bagi Pemerintah Daerah dan Instansi Terkait}

1. Mampu memprediksi jumlah kebutuhan masyarakat khususnya perempuan single parent dalam kegiatan pembangunan; baik struktur maupun nonstruktur yang langsung menyentuh kepada sasaran

2. Mengurangi tingginya angka pengangguran, angka kemiskinan dan menghindari tingginya konflik sosial akibat kemiskinan, rendahnya SDM, dan memetakan garis kebijakan yang lebih berorientasi pada permasalahan konkrit yang dihadapi masyarakat dalam hal ini termasuk bagi perempuan single parent

3. Mengurangi diskriminasi atau ketimpangan sosial (social difference) yang berkembang dalam masyarakat dan mengakomodir serta memfasilitasi masyarakat sesuai dengan hak dan kewajiban mereka

4. Menumbuhkembangkan nilai-nilai sosial dan nilai-nilai budaya dalam masyarakat tanpa menghilangkan identitas mereka dengan melestarikan nilai-nilai kelokalan atau kearifan lokal yang ada dan memberikan ruang kepada masyarakat untuk menyelesaikan masalahnya sendiri secara bersama-sama

5. Memberikan informasi yang memadai bagi pemerintah sebagai dasar untuk membuat kebijakan yang langsung menyentuh kepentingan rakyat kecil.

\section{Kemandirian Dampingan}

Program pemberdayaan perempuan single parent di Kenagarian Batu Hampa memerlukan keterlibatan semua pihak secara khusus dan serius, program pemberdayaan dengan pendekatan PAR sebagai salah satu upaya untuk mengatasi masalah yang dihadapi oleh perempuan single parent. Oleh karena itu ada beberapa analisis yang dapat dilakukan selama program pemberdayaan ini berjalan, yaitu:

1. Kenagarian Batu Hampa yang menjadi sasaran pemberdayaan, jika dilihat dari letak dan kondisi geografisnya sangat strategis namun tidak ditunjang oleh SDM yang memadai dalam hal pemanfaatan pekarangan, hal ini berdampak terhadap kestabilan ekonomi rumah tangga perempuan single parent. Berdasarkan pengakuan mereka, pekarangan belum termanfaatkan secara maksimal, dan belum dijadikan sebagai salah satu alternative pemenuhan kebutuhan. Realitas ini tidak disikapi secara positif dengan mengatur pekarangan dengan teknik yang sesuai dengan kondisi pekarangan. Oleh karena itu pemberdayaan dan pemanfaatan pekarangan dapat merubah pola hidup mereka yang selalu membeli dalam memenuhi kebutuhan rumah tangga.

2. Adanya kecenderungan sikap aparat yang tidak berpihak kepada perempuan, sehingga masalah yang dihadapi masyarakat seringkali dijadikan komoditas untuk mendapatkan keuntungan sendiri oleh pihak-pihak tertentu dan tidak pernah langsung menyentuh kepentingan masyarakat apalagi mencari solusi konkrit yang dapat melepaskan masyarakat dari permasalahan yang dihadapi. Seperti diakui oleh mereka bahwa bantuan seperti proyek dan bantuan peralatan hanya sampai kepada aparat desa atau keluarga dekat aparat desa setempat. Selanjutnya 
3. kalaupun sampai ke masyarakat tidak ada dampingan lanjutan.

4. Selama ini ada upaya peningkatan ekonomi masyarakat khususnya perempuan melalui program-program seperti PNPM mandiri. Tapi yang menjadi masalah adalah kurang adanya pemerataan bagi seluruh perempuan single parent. Perempuan single parent memiliki keterbatasan kemampuan dan pendanaan dalam pemanfaatan pekarangan. Oleh karena itu, Tim berkomitmen untuk memberdayakan masyarakat nagari dan kampung dengan prinsip tanggung jawab sosial, moral, dan kemanusiaan kepada masyarakat mengupayakan pendampingan serta pemberdayaan perempuan single parent pada pengembangan sistem perekonomian mereka melalui pemanfaatan pekarangan, hal ini dilakukan karena perekonomian dan sistem perekonomian menjadi "penyambung nyawa" dan "tulang punggung" serta "penentu" kehidupan perempuan single parent (Raharjo, n.d.)

\section{Implikasi Teoritis}

Pendampingan yang dilakukan oleh Tim pada perempuan single parent kenagarian Batu Hampa, dilandaskan kepada konsep Paulo Freire tentang pendidikan yang membebaskan. Bagi Freire, pendidikan merupakan cara untuk melakukan perubahan sosial, kultural, politik, dan ekonomi secara fundamental (transformasi sosial). Dengan kata lain, apa yang dilakukan oleh Tim pada perempuan single parent di Kenagarian Batu Hampa, dimaksudkan untuk membangun kesadaran kritis individu dan kolektif terhadap masalah keadilan sosial, dan menguatkan masing-masing individu untuk berjuang merubahnya.

Dalam konteks ini, tindakan (action) yang dilakukan merupakan serangkaian proses memahami tatanan kehidupan secara kritis (voluntary participant in process). Di mana peneliti dan masyarakat setara, peneliti membantu masyarakat dalam menghadapi kemapanan sosial (status quo). Evaluasi diarahkan pada perubahan cara pandang, tanggungjawab dan peran individuindividu terhadap proses transformasi sosial. Untuk itu, penggunaan metode yang tepat, akan memberi dampak yang menentukan.

Dalam kaitan ini, Tim secara teoretis menggabungkan beberapa metode yang relevan, yakni: teory kritis, riset kritis dan refleksi, terhadap masalah (problem possing), serta analisa sosial. Konsep pendidikan yang membebaskan sebagai esensi kehadiran Tim di Kenagarian Batu Hampa, mengharuskan peneliti memiliki keyakinan bahwa ketidakadilan sosial adalah diciptakan (constructed) dan karenanya dapat diubah, keberpihakan dan keretaan untuk berbuat (commitment) demi perbaikan keadaan kehidupan kelompok dhuafa' dan terdzolimi, berkeyakinan bahwa masyarakat memiliki pengetahuan yang berguna dan mereka dapat bekerja untuk memecahkan problem mereka sendiri, dan berpegang pada proses kesadaran kritis masyarakat untuk mampu dan berani menyatakan diri mereka sendiri, membuat visi alternatif untuk perjuangan hidup mereka ke depan.

Oleh karena itu keteguhan pada prinsip-prinsip yang selalu menjadi acuan bagi Tim dalam setiap program pendampingan masyarakat yang dilakukan, akan selalu menjadi komitmen peneliti. Prinsip yang dimaksud adalah berpegang pada strategi membantu rakyat untuk merumuskan perjuangan mereka sendiri dan membuat suara mereka menjadi terdengar, berorientasi "peningkatan kesadaran kritis" masyarakat untuk mengorganisir diri, dari proses pengorganisasian yang hanya untuk lingkup tunggal dan terbatas (singgle event) kepada pengorganisasian yang lebih luas untuk melakukan tindakan bersama demi keadilan, dan memiliki visi membangun gerakan transformasi sosial. 
Untuk itu, para peneliti yang terjun ke lapangan bersama perempuan single parent telah dilengkapi keterampilan yang diperlukan, di antaranya: teknik analisa sosial struktural dan conjunctural (structural dan conjunctral analyses), teknik pemetaan sosial dan kawasan (social, geographical et ecological mapping), teknik komunikasi kemanusiaan ( hut-non communication skill), teknik fasilitasi belajar orang dewasa (adult learning facilitation), teknik vertikultural dan teknik advokasi (advocacy).

Akhirnya peneliti sebagai pendidik masyarakat harus secara internal selalu melakukan refleksi kritis, mempertanyakan, apakah telah terjadi perubahan sosial? Kearah mana perubahan sosial terjadi? Mengapa perubahan itu terjadi? Apakah kaum dhuafa' dan terdzolimi posisinya dalam perubahan sosial tersebut? Apakah telah muncul organisasi perempuan? Apakah proses demokrasi telah benar-benar berjalan? Apakah mereka yang terlibat dalam organisasi telah menjadikan organisasinya sebagai alat perjuangan kepentingannya? Dan, apakah telah muncul kebersamaan dalam tindakan di antara mereka? Singkat kata, kehadiran Tim di tengah-tengah perempuan single parent di Kenagarian Batu Hampa, adalah sebagai pendidik, organizer, fasilitator bukanlah tukang, tetapi intelektual yang memiliki komitment transformasi sosial.

Karenanya Tim memiliki multi peran dalam proses pendidikan rakyat. Dengan segala komitmen tersebut Tim akan mempersiapkan langkah-langkah berikutnya dalam pendampingan perempuan single parent di Kenagarian Batu Hampa, sampai mereka terbebas dari kesadaran naif, dan kesadaran mitos, menuju kesadaran kritis, dalam membebaskan diri mereka dari kungkungan relasi yang berat sebelah antara penguasa dan rakyat. Menuju kehidupan yang lebih baik dan bermartabat. Perempuan single parent di kenagarian Batu Hampa telah berani mengatakan tidak kepada relasi kekuasaan yang timpang, dan menghimpun diri dalam kelompok perempuan yang mandiri.

Pada tahap berikutnya, Tim akan mendampingi mereka menuju arah yang lebih baik untuk perbaikan nasib mereka, membuka akses penguasaan skill berorganisasi dan bertani dari dan oleh mereka, menuju sistem pertanian yang berkelanjutan, mandiri, dan berkeadilan. Mengupayakan peningkatan pemahaman terhadap hokum dan perceraian.

\section{KESIMPULAN DAN REKOMENDASI}

Berdasarkan program yang telah dilaksanakan dan mempertimbangkan hasil refleksi dan evaluasi kritis yang dibahas, maka dapat direkomendasikan hal-hal sebagai berikut:

\section{Perguruan Tinggi}

Diharapkan dapat menyiapkan pendidikan bagi masyarakat sebagai konsekuensi perubahan paradigma berpikir masyarakat khususnya perempuan, tentang pemenuhan kebutuhan dan pendidikan keagamaan. Kemudian diharapkan dapat memperkuat peran serta Perguruan Tinggi dalam pengabdian kepada masyarakat khususnya perempauan single parent di pedesaan. Selanjutnya meningkatkan kapasitas dan kemampuan Perguruan Tinggi dalam memformulasikan bentuk implementasi tanggung jawab sosial di masyarakat yang sesuai dengan kondisi obyektif. Melakukan kerjasama kemasyarakatan dalam kerangka menciptakan hubungan yang dinamis antara LSM/NGO. Masyarakat dan Pemerintah. Memberikan advokasi terhadap persoalan rumah tangga perempuan single parent terutama persoalan cerai liar.

2. Masyarakat Kenagarian Batu Hampa 
Praktik-praktik tradisional perkumpulan masyarakat harus diperkuat, diharapkan kepada masyarakat mampu melestarikan kembali kelompok masyarakat yang peduli terhadap perempuan single parent. Menumbuhkembangkan kesadaran kritis masyarakat akan pentingnya pengembangan ekonomi melalui pemanfaatan pekarangan. Mendapatkan informasi dan sumbangsih pemikiran dalam penataan tingkat kesejahteraan masyarakat khususnya keluarga perempuan single parent. Mempertegas bentuk pembinaan sehingga mereka memiliki keswadayaan yang simultan dalam meningkatkan kesejahteraan mereka sendiri.

\section{Pemerintah Daerah (pemegang kebijakan)}

Pemerintah Daerah (pemegang kebijakan) agar dapat menganalisis sistem budaya dan dinamika budaya masyarakat. Menganalisis secara kritis mengkaji permasalahan pembangunan dari sudut pandang sosial-budaya dalam pembangunan pedesaan. Membantu dan berperan serta dalam pemberdayaan perempuan baik secara langsung maupun tidak langsung. Memberikan masukan secara kritis terhadap kondisi masyarakat yang multietnik dan multikultur dalam menyelesaikan permasalahan ekonomi yang dihadapinya. Melahirkan kebijakan yang pro atau berpihak pada masyarakat bawah (grassrooth) khususnya perempuan dengan melalui pendekatan bottom up serta berbasis research.

\section{REFERENSI}

Ahmad, M., dkk. (2003). Penelitian Aksi Partisipatoris; Sebuah Pengantar. Yogyakarta: SUSDEC,.

Bitha, M. (2011). Metode Penelitian Partisipatoris dan Upaya Pemberdayaan: Panduan bagi Praktisi Lapangan. Jakarta: Yayasan Obor Indonesia,.
Dewi. (n.d.). Dewi, Perempuan 29 tahun, salah satu single parent, wawancara 06 Desember 2012.

Fakih, M. (n.d.). dkk. 2001. Pendidikan Popular, Membangun Kesadaran Kritis.

Faqih, M. (2010). Bebas Dari Neolibralisme. Yogyakarta: Insist.

George, S. (2007). Pangan, Dari Penindasan Sampai ke Ketahanan Pangan. Yogyakarta: Insist.

Kemmis, S., \& McTaggart, R. (2005). Participatory action research: Communicative action and the public sphere. Sage Publications Ltd.

Malin Mudo, S. (n.d.). Saiful Malin Mudo,laki-laki 43 tahun, Wali Nagari Batu Hampar, wawancara 10 September 2012. Data ini telah dicek kembali ketika melakukan mapping yang dilaksanakan pada tanggal 05 Desember 2012 kemudian diverifikasi berdasarkan data statistic dalam profil nagari.

Mansour, F. (2000). Pendidikan Popular, Membangun Kesadaran Kritis. Yogyakarta: Insist.

Mansour, F. (2001). Runtuhnya teori pembangunan dan globalisasi. Pustaka Pelajar, Yogyakarta.

Profil. (n.d.). Kenagarian Batu Hampar terletak pada bagian utara Kabupaten Pesisir Selatan, tepatnya di Kecamatan Koto XI Tarusan yang ebrjarak sekirat 50 km dari Kota Padang Sumatera.

Rahardjo, T., Fakih, M., \& Topatimasang, R. (2001). Pendidikan Popular Membangun Kesadaran Kritis. Insist Press, Januari.

Raharjo, D. (n.d.). Pangan, Energi dan Lingkungan Hidup Perspektif Islam.

Toto Suharto, M. A. (2012). Pendidikan Berbasis Masyarakat; Relasi Negara dan Masyarakat dalam Pendidikan. LKIS Pelangi Aksara. 